\title{
Досвід використання замісної ниркової терапії в пацієнтів під час екстракорпоральної мембранної оксигенації
}

\author{
Чернишук С. С. ${ }^{1}$, Висоцький А. Д. ${ }^{1}$, Адамовська О. А. ${ }^{1}$, Урін О. О. ${ }^{2}$, Жовнір В.А ${ }^{1}$ \\ ${ }^{1}$ ДУ «Науково-практичний медичний центр дитячої кардіології та кардіохірургії МОЗ України», м. Київ, Україна \\ ${ }^{2}$ Національна дитяча спеціалізована лікарня «ОХМАТДИТ», м. Київ, Україна
}

\begin{abstract}
Мета роботи. Проведення на базі одного центру ретроспективного аналізу впливу гострого пошкодження нирок (ГПН) на смертність пацієнтів, яким виконували екстракорпоральну мембранну оксигенацію (ЕKMO).

Матеріали та методи. На базі ДУ «НПМЦ ДКК» у період з 2014 по 2018 рік було проведено 11 процедур ЕКМО. Екстракорпоральну мембранну оксигенацію було розпочато у 7 (64 \%) пацієнтів у зв'язку з розвитком гострої серцевої недостатності; у $2(18 \%)$ - через пневмонію та розвиток гострого респіраторного дистрес-синдрому; в 1 (9\%) пацієнта причиною став сепсис та ще в 1 дитини (9\%) - аритмія. Під час лікування ГПН у наших пацієнтів ми застосовували дві методики: перитонеальний діаліз та модифіковану ультрафільтрацію. Для діалізу використовували розчин «Діавітек ПД» 4,25 \% компанії «Юрія-Фарм», для ультрафільтрації - гемоконцентратори Medos® та Terumo®.
\end{abstract}

Результати та обговорення. Кількість успішних процедур ЕКМО становила 7 (63,5 \%) з 11. Ми вважали процедуру ЕКМО успішною, якщо після деканюляції пацієнт прожив протягом 48 год. Із 7 успішно деканюльованих пацієнтів 3 (43\%) були виписані з лікарні.

311 пацієнтів в 1 дитини (9\%) функція нирок була збережена, а в 10 (91\%) розвинулося ГПН AKIN3. У зв'язку з ГПН для замісної терапії 6 (55 \%) дітям проводили ультрафільтрацію, 1 (9\%) - перитонеальний діаліз; у 3 (27 \%) дітей терапію не проводили.

Після запуску ЕКМО ми суттєво покращили кровообіг. За рахунок здійснення ефективної перфузії тканин досягли нормалізації рівня сироваткового лактату на 2-у добу після запуску ЕКМО, діурез відновився на 3-ю-4-у добу, рівень креатиніну знизився на 8-9-у добу.

Усі пацієнти, що перебували на замісній нирковій терапії, мали позитивну динаміку в лікуванні ГПН, але 3 летальним наслідком за рахунок інших причин. Загальна летальність становила $73 \%$.

Висновки. Екстракорпоральна мембранна оксигенація - це процедура, що дозволяє проводити доставку кисню в критичних пацієнтів, коли інші методи інтенсивної терапії неефективні. У 90 \% пацієнтів, яким виконували ЕКМО, розвинулося ГПН, що потребувало проведення замісної терапії, в тому числі і ультрафільтрації. Гостре пошкодження нирок, що потребує замісної терапії, $є$ предиктором погіршення перебігу захворювання та підвищення летальності в дітей із вродженими вадами серця, які перенесли оперативне втручання з використанням апарату штучного кровообігу. Проведення ультрафільтрації не супроводжувалося розвитком ускладнень та давало змогу отримати від'ємний водний баланс.

Ключові слова: гостре пошкодження нирок, ультрафільтрація, перитонеальний діаліз, екстракорпоральна мембранна оксигенація, вроджена вада серия.

Вступ. У післяопераційний період у пацієнтів дитячого віку, особливо в новонароджених, із вродженими вадами серця (ВВС) виникають низка ускладнень. Серед них виділяють гостре пошкодження нирок (ГПН) та значний позитивний водний баланс. До факторів ризику виникнення ГПН при ВВС відносять вік і зрілість (< 12 міс. та недоношеність); тривалий час штучного кровообігу; синдром малого серцевого викиду; прямий пошкоджуючий вплив нефротоксичних препаратів; низький рівень гемоглобіну в доопераційний період; високі ризики за шкалою Risk Adjustment for
Congenital Heart Surgery (RACHS-1); тривала інфузія вазопресивних препаратів; сепсис; екстракорпоральна мембранна оксигенація [1-5]. За різними даними, частота виникнення ГПН у новонароджених після кардіохірургічного втручання становить 9-59 \% [6-9]. Це ускладнення обумовлене використанням штучного кровообігу (ШК), що призводить до зниження перфузії нирок і розвитку системної запальної реакції у відповідь на контакт з відкритим контуром апарата ШК. Тяжка форма ГПН асоційована з довготривалою штучною вентиляцією, необхідністю інотропної підтримки, 
тривалим перебуванням у відділенні інтенсивної терапії та подовженим терміном госпіталізації [1, 7, 8]. Пацієнти, в яких унаслідок ускладненого післяопераційного періоду розвивається поліорганна недостатність, можуть потребувати проведення екстракорпоральної мембранної оксигенації (ЕКМО). Екстракорпоральна мембранна оксигенація - це інвазивний короткотривалий метод підтримки життєдіяльності пацієнта, в якого діагностовано виражену легеневу або серцеволегеневу недостатність.

Ініціація ЕКМО призводить до посилення системної запальної реакції, гемолізу та зрушень у згортальній системі крові. Усі перераховані фактори спричинюють посилення ГПН, оліго-/анурії та необхідності в проведенні замісної ниркової терапії. Діти, в яких розвивається ГПН під час ЕКМО та які отримують замісну ниркову терапію, мають значно вищі ризики розвитку негативних результатів. Вірогідність летального наслідку в таких пацієнтів збільшується з 47 до $100 \%$ залежно від ступеня ГПН [4, 9]. Ми проаналізували цю закономірність серед наших пацієнтів.

Мета роботи. Проведення на базі одного центру ретроспективного аналізу впливу ГПН на смертність пацієнтів, у яких проводили ЕКМО.

Матеріали та методи. На базі ДУ «НПМЦ ДКК» у період з 2014 по 2018 рік було проведено 11 процедур ЕКМО. За деякими рекомендаціями, успішною процедура ЕКМО вважається, якщо після деканюляції пацієнт прожив протягом 48 год [10]. Медіана віку серед пацієнтів, яким виконували ЕКМО становила 3 міс. Серед них шестеро були чоловічої статті, п'ятеро - жіночої (таблиця 1).

\section{Таблиця 2}

Cтадії гострого пошкодження нирок (AKIN)

\begin{tabular}{|c|c|c|}
\hline Стадія & Сироватковий креатинін (SCr) & Дiурез \\
\hline I & $\begin{array}{l}\uparrow S C r \geqslant 26,5 \text { мкмоль/л або } \uparrow S C r \geqslant \\
150 \text { до } 200 \% \text { (१у } 1,5-2 \text { роки) }\end{array}$ & $\begin{array}{l}<0,5 \text { мл/кг/год } \\
\text { (> } 6 \text { год) }\end{array}$ \\
\hline II & 个SCr > 200 до & $\begin{array}{l}<0,5 \text { мл/кг/год } \\
\text { (> } 12 \text { год) }\end{array}$ \\
\hline III & $\begin{array}{l}\uparrow \mathrm{SCr}>300 \% \text { (> у } 3 \text { роки) або } \\
\text { якщо вихідний рівень } \mathrm{SCr} \geqslant 353,6 \\
\text { мкмоль/л, то } \uparrow \mathrm{SCr} \geqslant 44,2 \text { мкмоль/л }\end{array}$ & $\begin{array}{l}<0,3 \text { мл/кг/год } \\
\text { (24 год) або } \\
\text { анурія (12 год) }\end{array}$ \\
\hline
\end{tabular}

За визначенням авторів, ГПН - це стан, при якому сироватковий креатинін підвищується на $\geq 50 \%$ від вихідного рівня [7-9]. Для оцінювання ГПН у своїй практиці ми спирались на Acute Kidney Injury Network (AKIN) classification, де основними критеріями оцінювання є рівень приросту креатиніну та/або ступінь оліго-/анурії (таблиця 2).

Під час лікування ГПН у наших пацієнтів ми застосовували дві методики: перитонеальний діаліз $(\mathrm{n}=1)$ та ультрафільтрацію $(\mathrm{n}=6)$. Для перитонеального діалізу використовували розчин «Діавітек ПД» 4,25\% компанії «Юрія-Фарм». Щогодини протягом 15 хв через перитонеальний дренаж проводили інстиляцію розчину в кількості 10 мл/кг, час експозиції становив 20 хв, час дренажу ексудату - 25 хв.

Ультрафільтрація - метод видалення надлишкової рідини з організму пацієнта за допомогою гемоконцентратора. Метою цієї процедури є зменшення набряків тканин пацієнта та запобігання гемодилюції.

Таблиця 1

Структура пацієнтів, які потребували проведення ЕКМО

BBC Вік Стать Причина потреби ЕКМО

Замісна терапія під час ЕКМО

Тривалість ЕКМО

\begin{tabular}{|c|c|c|c|c|c|}
\hline ТМС + ДМШП & 3 дні & 4 & Сепсис & Ультрафільтрація & 35 год \\
\hline ДМШП + КоАо & 1 mic. & 4 & $\mathrm{CH}$ & Ультрафільтрація & 373 год \\
\hline ТМС + ДМШП & 24 дні & 4 & Пневмонія & Ультрафільтрація & 542 год \\
\hline $\mathrm{ABK}+\Pi \mathrm{\Pi BMC}$ & 5 мic. & 世 & $\mathrm{CH}$ & Ультрафільтрація & 212 год \\
\hline ТФ & 3 міс. & ж & Аритмія & Не отримував & 72 год \\
\hline ПВМС & 3 роки & ж & $\mathrm{CH}$ & Не отримував & 106 год \\
\hline Пухлина середостіння & 3 роки & 世 & $\mathrm{CH}$ & Не отримував & 69 год \\
\hline Множинні ДМШП + КоАо & 4 міс. & ж & $\mathrm{CH}$ & Перитонеальний діаліз & 360 год \\
\hline ПВМС & 1 день & 4 & $\mathrm{CH}$ & Ультрафільтрація & 110 год \\
\hline ПВМС & 1 день & 4 & $\mathrm{CH}$ & Ультрафільтрація & 148 год \\
\hline $\mathrm{AoCT}, \mathrm{AH}$ & 7 міс. & 4 & Пневмонія, ГРДС & Не отримував & 305 год \\
\hline
\end{tabular}

Примітка. ВВС - вроджена вада серця; ТМС - транспозиція магістральних судин; ДМШП - дефект міжшлуночкової перегородки; КоАо - коарктація аорти; АВК - атріовентрикулярна комунікація; ТФ - тетрада Фалло; ПВМС - подвійне відходження магістральних судин від правого шлуночка; АоСт - аортальний стеноз; АН - аортальна недостатність; СН - серцева недостатність; ГРДС гострий респіраторний дистрес-синдром. 
У наших пацієнтів ми застосовували модифіковану ультрафільтрацію за допомогою гемоконцентраторів Medos ${ }^{\circledR}$ та Terumo ${ }^{\circledR}$.

3 метою запобігання повітряній емболізації перед приєднанням заповнювали гемоконцентратор кров’ю. Праймінг проводили безпосередньо з контура. За допомогою волюметричного інфузомата В. Braun контролювалась швидкість ультрафільтрації та в середньому становила 25 мл/кг. Додаткової гепаринізації гемоконцентратор не потребував, оскільки кров у контурі вже була гепаринізована. Контролюючи процес ультрафільтрації, ми поступово досягли оптимального водного балансу, зменшили набряки в пацієнтів та знизили потребу в переливанні донорської крові (за умови відсутності активної кровотечі).

Результати та обговорення. Аналізуючи отримані нами дані, кількість успішних відключень від ЕКМО становила 7 з 11. Троє з 11 (27\%) пацієнтів вижили та були виписані зі стаціонару.

За нашими даними, в однієї (9\%) дитини була збережена функція нирок; у решти 10 (91\%) пацієнтів розвинулася ГПН AKIN3. У 6 (55\%) пацієнтів спостерігався приріст сироваткового креатиніну в 2,5-3 рази після запуску ЕКМО, у 4 (36 \%) - значний позитивний водний баланс.

У 3 (27 \%) пацієнтів, які перебували у стані олігуpiï (< 0,5 мл/кг/год), діурез відновився протягом 48 год після запуску ЕКМО.

Шести (55\%) дітям з 11 проводили замісну ниркову терапію (ЗНТ) у вигляді ультрафільтрації, 1 (9\%) дитині - перитонеальний діаліз. Троє (27\%) дітей не отримували ЗНТ та були успішно деканюльовані й виписані з лікарні. Ще 1 (9\%) дитина, якій не проводили ЗНТ, померла.

Кількість пацієнтів, яким виконували ультрафільтрацію, становила 6 осіб. 3 них 3 було успішно деканюльовано, однак з інших причин вони померли; троє не вижили після відключення від ЕКМО. Усі пацієнти, що перебували на ЗНТ, мали позитивну динаміку в лікуванні ГПН, але з летальним наслідком за рахунок інших причин. Загальна летальність досягла $73 \%$.

Після запуску ЕКМО ми суттево покращили кровообіг. За рахунок здійснення ефективної перфузії тканин досягли нормалізації рівня сироваткового лактату. Вимірювання цього показника проводили 6 разів на добу шляхом аналізу зразка артеріальної крові в апараті Radiometer ABL 700. Нормалізація показника лактату в артеріальній крові спостерігалась на 2-у добу (рисунок 1).

На фоні нормалізації рівня лактату відновлення швидкості діурезу відбулось на 3-ю-4-у добу ЕКМО (рисунок 2).

Стійке зниження показника креатиніну відбулось на 8-9-у добу після запуску ЕКМО. Показник креа-

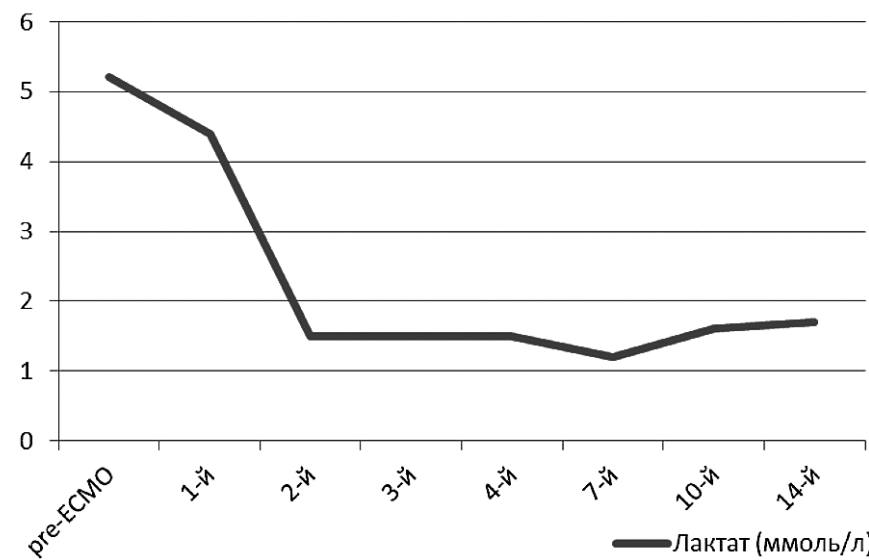

Рисунок 1. Динаміка середнього показника сироваткового лактату

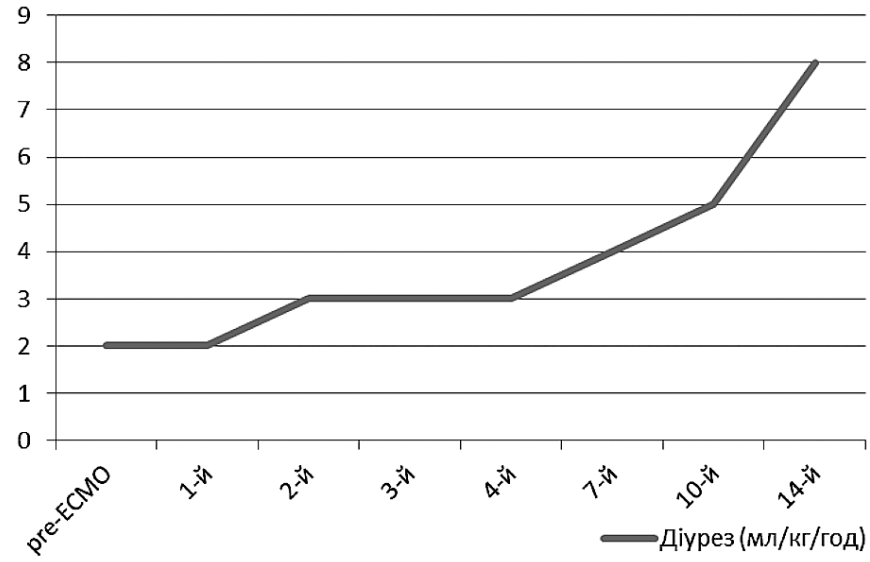

Рисунок 2. Динаміка середнього показника діурезу

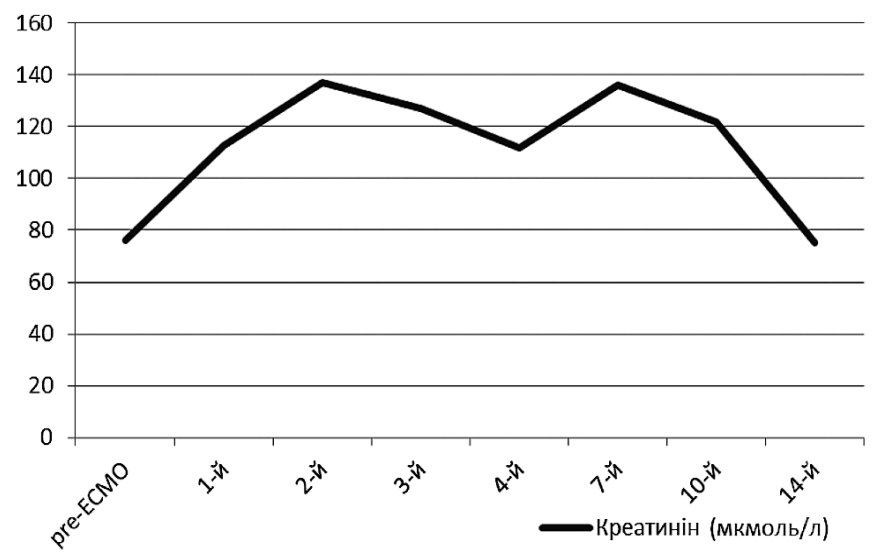

Рисунок 3. Динаміка середнього показника креатиніну 
тиніну вимірювали за допомогою біохімічного аналізу артеріальної крові 1 раз на добу (рисунок 3).

Один пацієнт помер через неможливість усунення хірургічним шляхом порушення геометрії коронарних судин; троє - через серцеву недостатність; один - через катетер-асоційований тромбоз верхньої порожнистої вени; двоє - унаслідок розвитку дихальної недостатності. Ще одна дитина померла у зв'язку з розвитком сепсису.

\section{Висновки}

1. Екстракорпоральна мембранна оксигенація - це процедура, що дозволяє оптимізувати доставку кисню в пацієнтів у критичному стані, якщо інші методи інтенсивної терапії неефективні. На це вказує динаміка лактату, що досягає норми в середньому на 2-у добу. За умови, що зміни, які призвели до тяжкого стану, є зворотними, ЕКМО дозволяє отримати додатковий час для проведення лікувальних заходів як терапевтичних, так і хірургічних.

2. Розвиток ГПН спостерігався у $90 \%$ пацієнтів, яким проводили ЕКМО.

3. Уведення в контур ЕКМО ультрафільтраційної колонки не супроводжувалось ускладненнями, що дозволяє зробити висновок про безпечність цієї процедури.

4. Ультрафільтрація в пацієнтів, яким проводили ЕКMO, з анурією та ГПН AKIN3 дає змогу отримати від'ємний водний баланс.

5. Незалежно від причини призначення пацієнту ЕКМО ГПН, що потребує замісної терапії, є предиктором погіршення перебігу захворювання в дітей з ВВС після кардіохірургічного втручання.

\section{Список використаних джерел} References

1. Park SK, Hur M, Kim E, Kim WH, Park JB, Kim Y, et al. Risk Factors for Acute Kidney Injury after Congenital Cardiac Surgery in Infants and Children: A Retrospective Observational Study. PloS One. 2016;11(11): e0166328. https://doi.org/10.1371/journal.pone.0166328

2. Sethi SK, Kumar M, Sharma R. Acute kidney injury in children after cardiopulmonary bypass: risk factors and outcome. Indian Pediatr. 2015;52(3):223-6.
3. Pedersen KR, Povlsen JV, Christensen S, Pedersen J, Hjortholm K, Larsen SH, et al. Risk factors for acute renal failure requiring dialysis after surgery for congenital heart disease in children. Acta Anaesthesiol Scand. 2007;51:13449. https://doi.org/10.1111/j.1399-6576.2007.01379

4. Fleming GM, Sahay R, Zappitelli M. The Incidence of Acute Kidney Injury and Its Effect on Neonatal and Pediatric Extracorporeal Membrane Oxygenation Outcomes: A Multicenter Report From the Kidney Intervention During Extracorporeal Membrane Oxygenation Study Group. Pediatr Crit Care Med. 2016;17(12):1157-69. https://doi. org/10.1097/PCC.0000000000000970

5. Tyth R, Breuer T, Cserép Z, Lex D, Fazekas L, Sбpi E, et al. Acute Kidney Injury Is Associated With Higher Morbidity and Resource Utilization in Pediatric Patients Undergoing Heart Surgery. Ann Thorac Surg. 2012;93:1984-90. https://doi.org/10.1016/j.athoracsur.2011.10.046

6. Piggott KD, Soni M, Decampli WM, Ramirez JA, Holbein D, Fakioglu $\mathrm{H}$, et al. Acute Kidney Injury and Fluid Overload in Neonates Following Surgery for Congenital Heart Disease. World J Pediatr Congenit Heart Surg. 2015 Jul;6(3):401-6. https://doi. org/10.1177/2150135115586814

7. Sarvesh Pal Singh. Acute kidney injury after pediatric cardiac surgery. Ann Card Anaesth. 2016;19(2):306-13. https://doi.org/10.4103/0971-9784.179635

8. Li S, Krawczeski CD, Zappitelli M, Devarajan P, ThiessenPhilbrook $\mathrm{H}$, Coca $\mathrm{SG}$, et al. Incidence, risk factors, and outcomes of acute kidney injury after pediatric cardiac surgery: A prospective multicenter study. Crit Care Med. 2011;39(6):1493-9. https://doi.org/10.1097/ CCM.0b013e31821201d3

9. Askenazi DJ, Ambalavanan N, Hamilton K, Cutter G, Laney D, Kaslow R, et al. Acute kidney injury and renal replacement therapy independently predict mortality in neonatal and pediatric noncardiac patients on extracorporeal membrane oxygenation. PediatrCrit Care Med. 2011 Jan;12(1):e1-6. https://doi.org/10.1097/ PCC.0b013e3181d8e348

10. Chang WW, Tsai FC, Tsai TY, Chang CH, Jenq CC, Chang MY, et al. Predictors of Mortality in Patients Successfully Weaned from Extracorporeal Membrane Oxygenation. PLoS One. 2012;7(8):e42687. https://doi.org/10.1371/ journal.pone.0042687

\title{
Experience of Use of Renal Replacement Therapy in Patients During Extracorporeal Membrane Oxygenation
}

\author{
Chernyshuk S. S. ${ }^{1}$, Vysotskyi A. D. ${ }^{1}$, Adamovska O. A. ${ }^{1}$, Urin O. O. ${ }^{2}$, Zhovnir V. A. ${ }^{1}$ \\ ${ }^{1}$ Ukrainian Children's Cardiac Center, Kyiv, Ukraine \\ ${ }^{2}$ National Children's Specialized Hospital “OKHMATDYT", Kyiv, Ukraine
}

\begin{abstract}
The aim. To provide retrospective single-center analysis of the influence of acute renal injury (ARI) on mortality in patients on extracorporeal membrane oxygenation (ECMO).

Materials and methods. On the basis of the Ukrainian Children's Cardiac Center in the period from 2014 to 2018 , 11 procedures of ECMO were conducted. ECMO was started in 7 (64\%) patients due to the development of acute heart
\end{abstract}


failure; in $2(18 \%)$ patients due to pneumonia and the development of acute respiratory distress syndrome; in $1(9 \%)$ patient it was carried out due to sepsis and in 1 child $(9 \%)$ due to arrhythmia. We used two methods to treat ARI in our patients: peritoneal dialysis and modified ultrafiltration. Diavitec PD $4.25 \%$ solution (Yuria-Pfarm) was used for dialysis, and Medos ${ }^{\circledR}$ and Terumo ${ }^{\circledR}$ hemoconcentrators were used for ultrafiltration.

Results and discussion. The number of successful ECMO procedures was $7(63.5 \%)$ out of 11. ECMO procedure was considered successful if, after decanulation, the patient lived for 48 hours. Of the 7 successfully decanulated patients, $3(43 \%)$ were discharged from the hospital.

Of the 11 patients, in 1 child $(9 \%)$, the kidney function was maintained, and $10(91 \%)$ patients developed acute kidney damage AKIN3. Due to the acute kidney damage, six (55\%) children underwent ultrafiltration as a replacement therapy; 1 (9\%) child had peritoneal dialysis; in $3(27 \%)$ patients no therapy was conducted.

After the start of ECMO, we significantly improved blood flow. Due to the effective perfusion of tissues, normalization of serum lactate level on the day 2 after ECMO, diuresis resumed on the day 3 or 4 , the level of creatinine decreased on the day 8 or 9 .

All the patients receiving renal replacement therapy (RRT) showed positive changes in terms of the treatment of ARI but had fatal outcome for other reasons. The total mortality was $73 \%$.

Conclusion. ECMO is a procedure that allows for the oxygen delivery in critical patients when other methods of intensive care are ineffective. AKI developed in $90 \%$ of patients on ECMO and required replacement therapy, including ultrafiltration. Acute kidney damage requiring replacement therapy is a predictor of the disease deterioration and increased mortality in children with congenital heart disease undergoing surgical intervention using a cardiopulmonary bypass. Ultrafiltration was not associated with the development of complications and allowed to achieve negative fluid balance.

Keywords: acute kidney injury, ultrafiltration, peritoneal dialysis, extracorporeal membrane therapy, congenital heart disease.

Стаття надійшла в редакцію 18.04.2019 p. 